\title{
Phototherapy in Neonatal Hyperbilirubinaemia - An Overview
}

\author{
Chitturi Venkata Sai Akhil ${ }^{1}$, Sachin Damke ${ }^{2}$ \\ 1,2 Department of Paediatrics, Jawaharlal Nehru Medical College, Datta Meghe Institute of Medical Sciences \\ (Deemed to Be University), Sawangi Meghe, Wardha, Maharashtra, India.
}

\section{ABSTRACT}

The first report on the use of phototherapy for treatment of neonates with jaundice was published more than 20 years ago. Since then, phototherapy has been used extensively in the treatment of neonatal hyperbilirubinaemia.

Phototherapy is the use of visible light for the treatment of hyperbilirubinaemia in the newborn. There are different types of phototherapy systems in use in recent times. Effectiveness of phototherapy depends on several factors which should be considered while delivering phototherapy to a jaundiced neonate. Effective phototherapy has decreased the need for exchange transfusion. Proper nursing care enhances the effectiveness of phototherapy and minimises complications.

Jaundice is benign in most of the cases, but because of potential bilirubin toxicity, strict and close monitoring is required. Prompt recognition and intervention of the infants at increased risk for developing hyperbilirubinaemia forms the first step in management. The focus is to prevent development of severe hyperbilirubinaemia by early recognition and initiation of treatment. Counselling of parents, especially mother also plays a major role in the treatment of neonatal jaundice. Recommended guidelines are intended to be used by hospitals and treating paediatricians, neonatologists and advanced practice nurses trained in neonatology.

Phototherapy devices include fluorescent, halogen, fibreoptic or light emitting diode light sources. Each type has its own benefits and side effects. Many studies were available comparing the efficacy of various types of phototherapy systems.

The purpose of this review article was to provide a conceptual review on role of phototherapy in neonatal jaundice, different types of phototherapy systems in use, recent advances and probable side effects of phototherapy.

\section{KEY WORDS}

Bilirubin, Hyperbilirubinaemia, Jaundice, Neonatal Intensive Care, Newborn, Phototherapy
Corresponding Author: Dr. Chitturi Venkata Sai Akhil, Junior Resident,

Department of Paediatrics, Jawaharlal Nehru Medical College, Datta Meghe Institute of Medical Sciences (Deemed to Be University), Sawangi Meghe, Wardha, Maharashtra, India.

E-mail: me.akhilpandu@gmail.com

DOI: $10.14260 / j e m d s / 2021 / 337$

How to Cite This Article:

Akhil CVS, Damke S. Phototherapy in neonatal hyperbilirubinaemia - an overview. J Evolution Med Dent Sci 2021;10(21):1621-1627, DOI: 10.14260/jemds/2021/337

Submission 15-01-2021,

Peer Review 21-03-2021,

Acceptance 29-03-2021,

Published 24-05-2021.

Copyright (c) 2021 JEMDS. This is an open access article distributed under Creative Commons Attribution License [Attribution 4.0 International (CC BY 4.0)] 


\section{BACKGROUND}

The word bilirubin was derived in 1868, from the latin word "bilis" = bile and "ruber" = red. Bilirubin is a yellowish-brown pigment that is derived from the breakdown of heme. It helps coordinate iron into various proteins, like haemoglobin, myoglobulin, P450 enzymes etc. It has been found to have antioxidant properties and helps in excreting heme from the body.

Jaundice was derived from the latin word "galbinus", which describes a greenish-yellow colour. This was termed "jaunisse" in Old French, which became jaundice in English. A common misconception is that the word jaundice arises from French word "jaune" which means yellow. Icterus was derived from the Greek word "Ikteros". This word refers to both the yellow discolouration and a yellow bird. Icterus is the latinised form of the word. It was believed earlier that a person who was jaundiced could be cured if he looked upon the yellow bird by transferring the disease to the yellow bird. Icterus is used interchangeably with jaundice. Both are used to describe the yellowish discolouration of the sclera and the skin caused due to increased bilirubin levels in blood.

\begin{tabular}{|c|c|c|}
\hline Year & Ancient Authors & $\begin{array}{l}\text { Description of Neonatal } \\
\text { Hyperbilirubinaemia }\end{array}$ \\
\hline Earliest references & $\begin{array}{l}\text { Babylonian Talmud / } \\
\text { Sumerian tablets }\end{array}$ & "sign of casteless hatred" \\
\hline $1500 \mathrm{BC}$ & Ebers papyrus & $\begin{array}{c}\text { Document - "first surviving account of } \\
\text { medical remedies" }\end{array}$ \\
\hline $1500 \mathrm{BC}$ & Isaac Asimov & $\begin{array}{c}\text { Book - "Chronology of science and } \\
\text { discovery" }\end{array}$ \\
\hline $1400 \mathrm{~s}$ & $\begin{array}{l}\text { Bartholomaeus Metlinger } \\
\text { (Chinese Literature) }\end{array}$ & $\begin{array}{c}\text { Book - "Ein regiment der jungen } \\
\text { Kinder" }\end{array}$ \\
\hline 1875 & $\begin{array}{l}\text { Johannes Orth (German } \\
\text { pathologist) }\end{array}$ & $\begin{array}{l}\text { Described the yellowish } \\
\text { discolouration of basal ganglia in a } \\
\text { jaundiced neonate }\end{array}$ \\
\hline \multicolumn{3}{|c|}{$\begin{array}{l}\text { Table1. Description of Neonatal } \\
\text { perbilirubinaemia by Ancient Authors }\end{array}$} \\
\hline
\end{tabular}

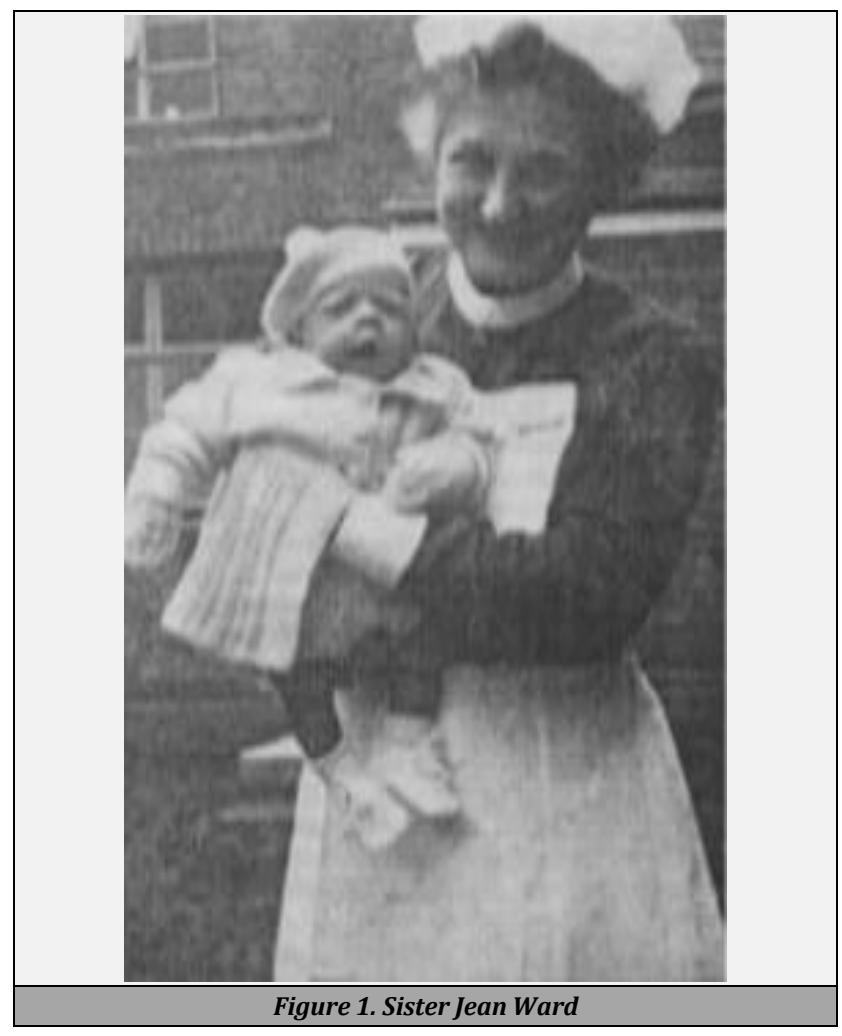

Father of modern phototherapy - "Faroese physician Niels Finsen". When natural sunlight was believed to be beneficial in the treatment of several skin disorders, he developed the first artificial light source especially for the treatment of lupus vulgaris. Later on, phototherapy was developed and used for the treatment of neonatal jaundice. Phototherapy is considered to be the visible light treatment for neonatal jaundice. ${ }^{1}$ Sister Jean Ward, the nurse in charge of the Premature Unit believed in the powers of fresh air and sunshine. But the doctors were not so keen about this belief and did not follow this practice that time. So, Sister Ward used to wheel the infants outdoor into the courtyard of hospital on sunny days, and returned them to the ward just before the doctor's rounds. One day in 1956, Sister Ward showed the doctors an undressed neonate whose skin was pale except for a triangular area covered by a cloth / sheet that appeared much yellower than the rest of the body which was uncovered and was let exposed to light. Subsequently doctors at Rochford Hospital found that the bilirubin levels had drastically dropped in patients who were left sitting under the sunlight which subsequently led to the idea of phototherapy in the treatment of a jaundiced newborn.

The first artificial light-based phototherapy unit was discovered by Cremer et al. at Rochford Hospital. In 1985 McDonagh and Lighter clarified the "physical and chemical alterations" that occur in this form of therapy. ${ }^{3}$

Bilirubin molecules are bound to collagen and lipoproteins in the interstitial space of epidermis. ${ }^{4}$ Phototherapy which emits light between 400 - $500 \mathrm{~nm}$ wavelengths, breaks the bonds between bilirubin and collagen-lipoproteins and increases the excretion of bilirubin. ${ }^{5}$ The decline in skin bilirubin levels is greater than that of serum bilirubin levels. ${ }^{6}$

\section{PHOTOTHERAPY REACTIONS}

\section{Photo-Oxidation}

It causes fragmentation in the structure of the bilirubin molecule. Absorption of photon by bilirubin molecule

- Bilirubin molecule gets stimulated.

- Envelopes an oxygen molecule.

- Transformation into free radical.

- Destruction of native bilirubin.

- Production of five renal excretion products.

This is a slow reaction and occurs in small quantities. ${ }^{8}$

\section{Photoisomerization}

It transforms the unaltered bilirubin molecule into hydrosoluble isomers. Bilirubin molecule can undergo 2 types of in vitro photochemical reactions: ${ }^{7}$ This is a faster reaction. Structural isomer (lumirubin)- Formation of this isomer is by formation of new bonds between $\mathrm{CH}-\mathrm{CH} 2$ groups of two adjacent rings involving $\mathrm{C} 2-\mathrm{C} 7(\mathrm{C}=$ carbons). It is a stable product (slow formation and rapid excretion). So, this product doesn't accumulate in the circulation. Hence, it is considered as the main efficacy factor of phototherapy. Formation of this isomer depends on luminous intensity.

Configuration isomer - Formation of this isomer involves $180^{\circ}$ rotation of the terminal ring on its axle by which polar segment ( $\mathrm{NH}$ and $\mathrm{COOH}$ ) gets exposed to the exterior involving $\mathrm{C} 4$ and C15. It has rapid formation and slow excretion, 
therefore accumulates in the circulation. Its formation doesn't depend on luminous intensity. This product is unstable and can revert to native form of bilirubin. ${ }^{9,10,11}$

\section{How to Measure the Efficacy of a Phototherapy Unit?}

A phototherapy unit can be considered efficient if it can reduce total bilirubin by $1-2 \mathrm{mg} / 24$ hours duration irrespective of other factors. ${ }^{12}$ The efficacy of a phototherapy unit can be known by quantifying the photoproducts by high performance liquid chromatography (HPLC). ${ }^{13,14}$

\section{Phototherapy Depends on Several Factors}

- Numbers of lamps

- Type of light

- Distance from the source

How to Determine the Irradiation of a Phototherapy Unit?

It is expressed in microwatts $\mathrm{mw} / \mathrm{cm} 2 / \mathrm{nm}$. Irradiation of phototherapy is directly proportional to efficacy of phototherapy ${ }^{15}$ for e.g., 6 microwatts / $\mathrm{cm} 2$ / nanometer is low intensity,; around 12 microwatts / $\mathrm{cm} 2$ / nanometer is high intensity (according to several authors) ${ }^{16}$,

According to Costarino et al. formation of structural isomer lumirubin depends on irradiation of phototherapy (high intensity phototherapy produces higher quantities of lumirubin) while the formation of configuration isomer doesn't depend on irradiation of phototherapy. According to Maisels, increasing irradiation beyond the saturation point (23 $\mathrm{mw} / \mathrm{cm} 2 / \mathrm{nm}$ ) does not raise efficacy. According to Tan, the saturation point should be $40 \mathrm{mw} / \mathrm{cm} 2 / \mathrm{nm} .{ }^{17}$

\section{Number and Type of Lamps}

Irradiation of a conventional phototherapy equipment is directly proportional to the number of lamps. ${ }^{18}$ Most of the studies recommend the use of traditional phototherapy equipment which requires 8 - 12 lamps. ${ }^{19}$ Recently one light halogen lamps have been used in some services irradiating 23 $\mathrm{mw} / \mathrm{cm} 2 / \mathrm{nm}$ range which concentrates emitted light in a small and non-uniform area.

\section{Time of Use}

White, fluorescent lamps show a decline in the irradiance of approximately $25 \%$ after 1 hour of use, which decreased to 44 $\%$ of initial irradiance at 2000 hours of use.$^{20}$ However, precise data and studies are not available which could conclude the ideal time for the use of phototherapy unit.

\section{Color of the Light}

Cramer described the use of 8 blue $40 \mathrm{~W}$ fluorescent lamps. ${ }^{21}$ It depends on the type of gas used: iodine, fluoride, neon or tungsten. According to Ennever there is no difference between the color of the lamps, and that blue light may not be as good as a conventional white lamp. White light is the most widely employed and the most easily found, seems to be satisfactory, as long as energy emission is kept above $6 \mathrm{mw} / \mathrm{cm} 2 / \mathrm{nm}$.

\section{Interference Factors}

The efficacy of a phototherapy unit can be affected by several factors which like any obstacle between phototherapy unit and exposed area, thermal blankets and poor quality of incubator (e.g., scratches). They should be given due consideration and appropriate interventions to improve the efficacy of phototherapy 22

\section{Phototherapy May Be Continuous or Intermittent}

Continuous phototherapy is without any interruptions. Intermittent phototherapy is therapy for an hour and off for an hour or on for 6 hours and off for 6 hours. Phototherapy may be single surface, double surface or triple surface.

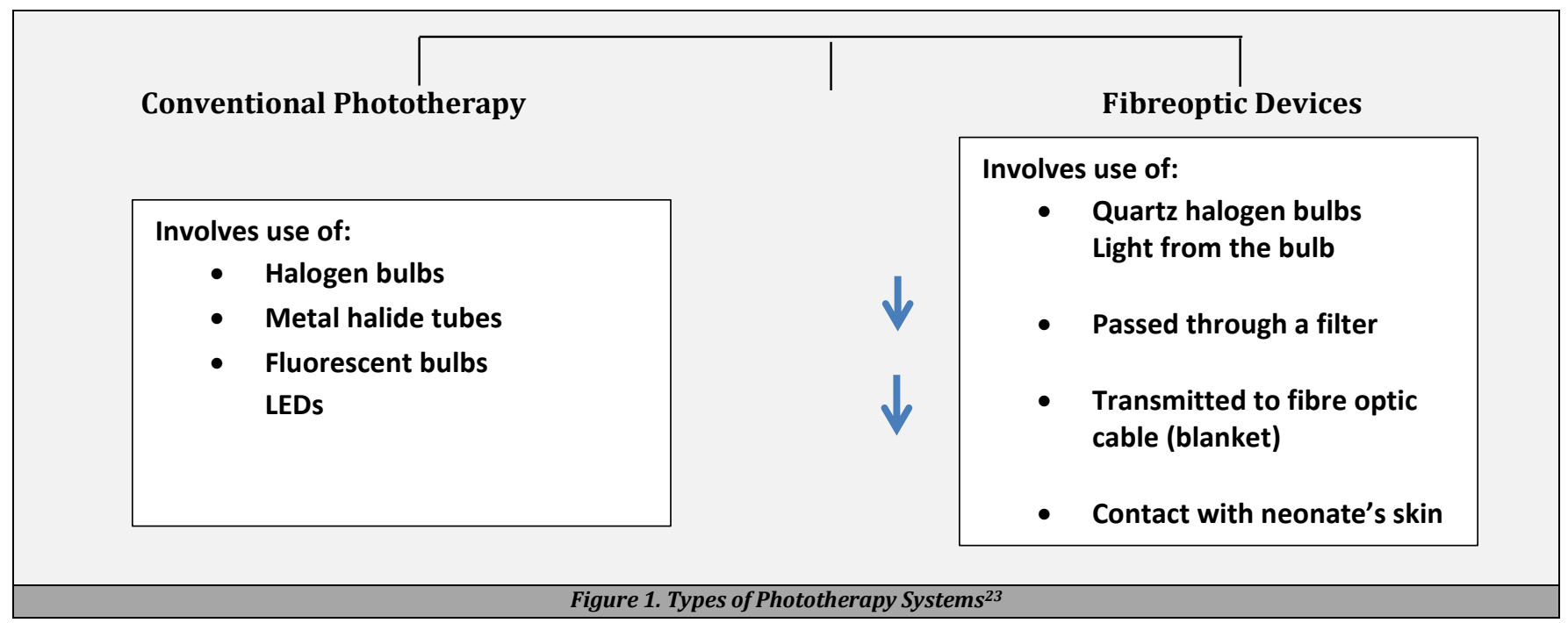




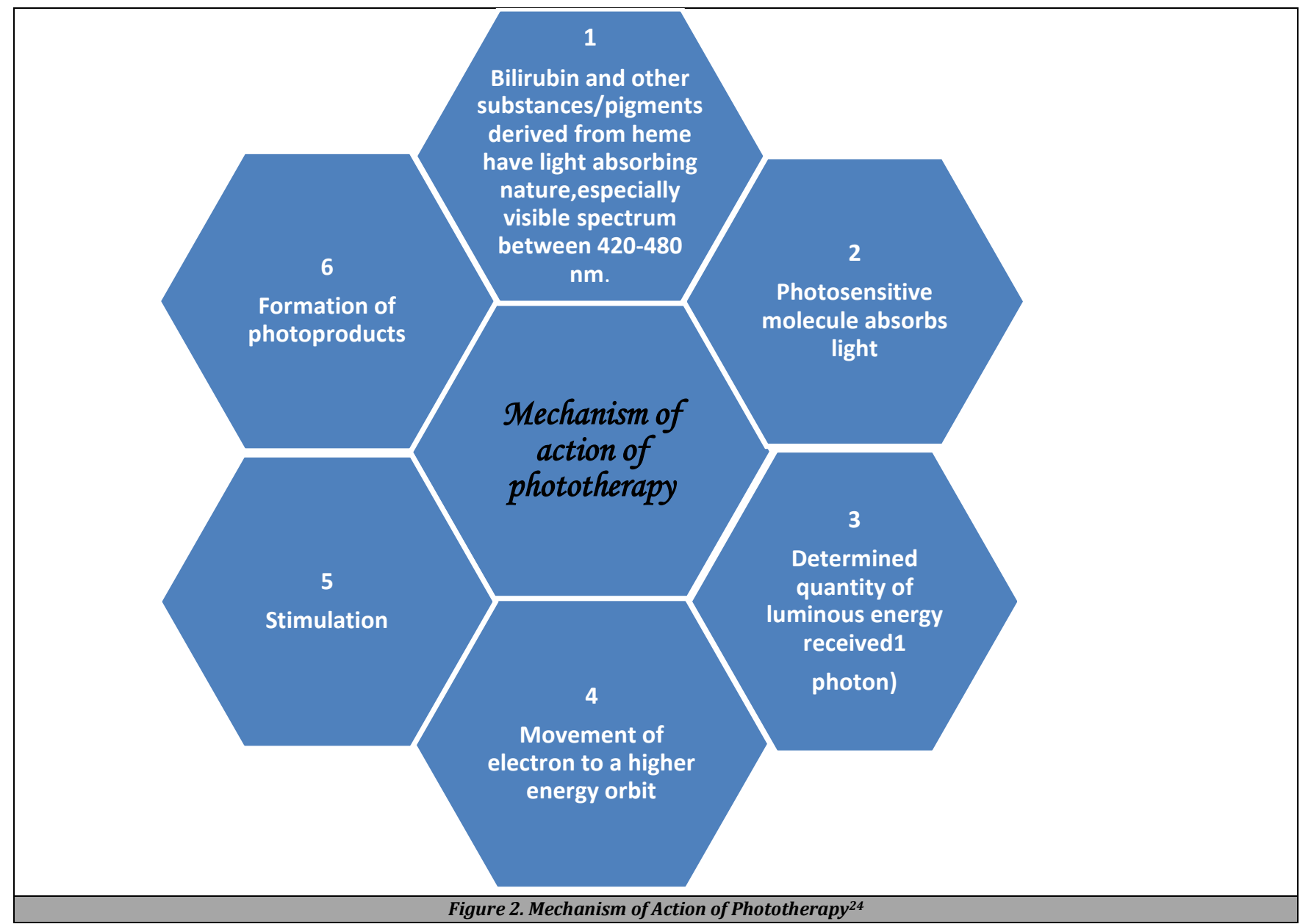

\section{RECENT ADVANCES IN PHOTOTHERAPY IN NEWBORNS}

Novel phototherapy systems are now available and widely used in some areas which have benefit of increased body surface area (BSA) exposed to phototherapy light and minimal or no interruptions during feeding.

A study was conducted at Hospital Universitario San Ignacio of Bogota, Colombia 25 called "BAG \& BLANKET TRIAL" where they have compared the efficacy of bilibags (bilinests) and biliblankets with conventional phototherapy system by a randomised control trial. In blanket trail, patients received phototherapy with the latest NeoMed Light Bilicocoon Nest or Ohmeda biliblanket. In bag trial patients received phototherapy with NeoMed Blilcocoon bag (sleeping bag with dorsal and ventral light exposure). The parameter under check were serum bilirubin levels (rate of decline) and axillary temperature while taking other interfering factors into consideration. Both bag and blanket groups were then compared with the conventional phototherapy with fluorescent light. On comparison between bag trial group and conventional phototherapy it was found that patients in bag trial have greater proportion of cases with early onset jaundice, but the decrease in serum bilirubin level was found to be similar in both the groups. The difference in body temperature was also clinically insignificant.

Another study was conducted at newborn intensive care unit (NICU), Government Medical College, Kashmir, in which they had compared the efficacy of light emitting diode (LED) phototherapy with conventional phototherapy. ${ }^{26}$ The parameters considered were: rate of fall of serum bilirubin levels and duration of phototherapy (Kaplan-Meier analysis) required. They have found that the efficacy of LED phototherapy was more superior to conventional phototherapy considering both the parameters. In addition, patients who received LED phototherapy were at lower risk of reaching threshold for exchange transfusion when compared to those who received conventional phototherapy.

A non-randomised prospective interventional study was conducted in a tertiary care hospital of Western India in which they have compared the efficacy of 3 types of phototherapy systems: i) Blue-White Standard-Length Tube Light Phototherapy (B \& W), ii) Compact fluorescent light (CFL) phototherapy, and iii) LED phototherapy. ${ }^{27}$ The parameters considered were mean value of total bilirubin obtained after 24 hours of phototherapy and need for exchange transfusion. They have found that mean change in total serum bilirubin (TSB) level after $24 \mathrm{hrs}$. of phototherapy was not statistically significant in 3 types of phototherapy systems under study and had stated that more superior trials will be needed to judge the superiority of these 3 types.

\section{NURSING CARE OF AN INFANT UNDER A PHOTOTHERAPY UNIT}

Nursing care severely affects the efficacy of phototherapy delivery, and ultimately the rate of fall of total serum bilirubin level and length of hospital stay. 
- $\quad$ Provide eye protection: This is done with the help of opaque eye patches / eye shields placed on the eyes of infant receiving phototherapy.

- Assess skin exposure: Assessment of area of skin exposed to phototherapy light should be done so as to expose the maximum possible surface area to light.

- $\quad$ Proper positioning: Frequent repositioning of infants to expose different body areas is not recommended to improve the efficacy of phototherapy.

- Hydration: Several studies proved that increased hydration of infant can shorten the duration of phototherapy.

- Promotion of parent and child interaction: Minimal interruptions of phototherapy is accepted to promote mother-baby interaction, emotional bonding, Kangaroo mother care (skin to skin contact).

\begin{tabular}{|c|c|}
\hline Short Term & Long Term \\
\hline Interferes with mother-baby bonding and interaction & Allergic diseases \\
\hline Thermal \& hydration imbalance & $\begin{array}{l}\text { Melanocytic nevi, melanoma } \\
\text { and skin cancer }\end{array}$ \\
\hline Loose stools & Ocular side effects \\
\hline Electrolyte disturbances & Patent ductus arteriosus (PDA) \\
\hline \multicolumn{2}{|l|}{ Hypocalcemia } \\
\hline \multicolumn{2}{|l|}{ Circadian rhythm disturbances } \\
\hline \multicolumn{2}{|l|}{ Bronze baby syndrome } \\
\hline \multicolumn{2}{|l|}{ Riboflavin deficiency } \\
\hline \multicolumn{2}{|l|}{ Bullous eruptions } \\
\hline \multicolumn{2}{|l|}{ DNA damage } \\
\hline \multicolumn{2}{|l|}{ Retinal damage } \\
\hline \multicolumn{2}{|l|}{ Haematological side effects } \\
\hline Table 3. Side Effects of Phot & totherapy \\
\hline
\end{tabular}

These were a few studies in which the side effects of phototherapy were proved to some extent in the selected study population. The side effects of phototherapy include -

\section{Interferes with Mother Baby Bonding and Interaction 28}

Neonatal phototherapy interferes with mother baby bonding and neonatal auditory and visual orientation and alertness. It also increases anxiety in parents. Hence unless jaundice is severe, phototherapy can be interrupted for breastfeeding.

\section{Thermal and Hydration Imbalance ${ }^{29}$}

Conventional phototherapy may cause insensible water losses, hypothermia / hyperthermia, dehydration and intestinal fluid losses. Hence, close monitoring and appropriate fluid supplementation is necessary for maintaining fluid balance and temperature in newborn.

\section{Loose Stools 30}

A study conducted at Department of Paediatrics, Second School of Medicine, University of Naples, Italy in which faecal osmolality and electrolyte concentrations were measured in study groups who received phototherapy and control groups who did not receive phototherapy to find out the cause of diarrhoea in newborns receiving phototherapy. The result showed an increase in intestinal secretion in neonates who received phototherapy for neonatal hyperbilirubinaemia which was the cause of watery stools. Absorption of water, sodium chloride and potassium was significantly impaired in the patients receiving phototherapy; but it was found to be a transient effect which was not apparent after stopping phototherapy.

\section{Hypocalcemia 31}

A cross sectional study was conducted at Koodakan Hospital in Bandar Abbas which aimed to determine the prevalence of hypocalcemia in the neonates receiving phototherapy. The study groups were divided as neonates $<3$ days and $>$ days. Serum calcium levels were sent before the start of phototherapy and 48 hours after phototherapy, which showed $9 \%$ prevalence of hypocalcemia in those neonates receiving phototherapy. The study also proved that phototherapy does not increase the risk of hypocalcemia in full term, healthy newborns. Hence there is no need of prophylactic calcium in such newborns.

\section{Circadian Rhythm Disturbances ${ }^{32}$}

A study conducted by Chen et al. proved that phototherapy has an effect on circadian genes in peripheral circulation of mononuclear cells of jaundiced neonates e.g., Cry1 gene increased expression and decreased plasma melatonin leading to frequent crying and jitteriness in newborn. Therefore, timing of phototherapy is required to accommodate normal circadian rhythm of newborn.

\section{Bronze Baby Syndrome (BBS) ${ }^{33}$}

It is a rare complication that occurs due to a rise in conjugated bilirubin (cholestasis). Copper $(\mathrm{Cu})$-protoporphyrin in metabolism disturbance and congenital biliary hypoplasia are the predictable causes of BBS. It may be transient and may disappear if phototherapy is discontinued or may have additional risk of kernicterus.

\section{Riboflavin Deficiency}

Many previous studies conclusively reported that riboflavin in body cells is degraded by phototherapy. It occurs due to red blood cells (RBC) lysis because of deficiency of glutathione reductase in RBC. Gromisch et al. ${ }^{34}$ proved that 16 / 21 infants who received phototherapy developed riboflavin deficiency. Amin HJ et al. ${ }^{35}$ measured flavin adenine mononucleotide saturation of RBC glutathione reductase which proved that all neonates who received phototherapy in the study sample developed riboflavin deficiency.

\section{Bullous Eruptions}

It occurs due to porphyrins in peripheral circulation. Paller AS et al. $^{36}$ studied the relation between the eruption and porphyrin levels and reported that occurrence of eruptions in light exposed areas and circulating porphyrins suggest that porphyrinaemia may be the underlying cause of bullous and purpuric eruption.

\section{Deoxyribonucleic Acid (DNA) Damage}

Phototherapy can cause oxidative damage to cell membrane and cause free radical injury to DNA. El Abdin MY et al. ${ }^{37}$ 
reported that phototherapy causes increased DNA fragmentation in lymphocytes of peripheral circulation when compared to DNA before the start of phototherapy. Tatli MM et $\mathrm{al}^{38}$ proved as the duration of phototherapy increased, damage to the DNA also significantly increased by alkaline comet assays.

\section{Thrombocytopenia ${ }^{39}$}

A prospective study was conducted at a tertiary care hospital. The study included all neonates who required phototherapy as per the protocol of American Academy of Pediatrics. It was found that majority of neonates who received phototherapy had thrombocytopenia especially after 24 hours of phototherapy. There were other similar studies (Maurer et al.) in which platelet counts were checked after 48 and 96 hours of phototherapy. Incidentally none of the newborns with thrombocytopenia had signs of bleeding manifestations which later proved that thrombocytopenia due to phototherapy is a transient effect and rarely found to be severe enough to cause bleeding.

\section{Phototherapy and Decrease in Serum Globulin Levels 40 \\ A study was conducted in NICU, Zhongnan Hospital of Wuhan University (Wuhan, China) which aimed to assess / prove one of the side effects of phototherapy in neonates. According to previous studies, phototherapy is associated with some immune disorders of childhood later in life. The reason for the occurrence of these immune disorders is that phototherapy causes a decrease of globulin levels in serum. The main aim of this study was to assess the relation of phototherapy on serum albumin and globulin levels. The study summarized a decline in serum globulin levels in those groups who received phototherapy and some of them required intravenous immune globulin (IVIG) infusion, with a minimal or no effect on serum albumin levels.}

Melanocytic Nevi, Melanoma and Skin Cancer ${ }^{41}$ Phototherapy can cause damage to nuclear and mitochondrial DNA and can cause free radical damage leading to skin cancer. Previous studies conducted by Matichard E et al. postulated that larger nevi $>2 \mathrm{~mm}$ are at significantly higher risk in phototherapy exposed groups when compared to controls who did not receive phototherapy.

\section{Ocular Side Effects}

There is an increased incidence of retinopathy of prematurity due to decreased oxidation resistance and increased free radical production. It is also postulated that phototherapy causes increased risk of uveal melanoma due to higher penetrance of blue light compared to UV light when baby's eyes were not covered with an eye patch.
Patent Ductus Arteriosus (PDA) ${ }^{42}$

Mechanism - Absorption of photons by cardiac cells $\rightarrow$ relaxation of aortic smooth muscle cells via nitric oxide system $\rightarrow$ decreased mean arterial pressure $\rightarrow$ increased peripheral blood flow

All these mechanisms cause ductus arteriosus to relax and keep open. Guo Sheng Liu et al. proved that phototherapy caused an increase in blood endothelin levels after 24 hours of phototherapy and increased nitric oxide (NO) levels after 12 and 24 hours of start of phototherapy when compared to pretreatment values which ultimately resulted in relaxation of aortic smooth muscle and patent ductus arteriosus.

\section{CONCLUSIONS}

Phototherapy is a safe and inexpensive modality of treatment for neonatal jaundice. It has become the mainstay of treatment of neonatal jaundice. It is highly necessary for all the health centres to evaluate the efficacy and quality of their phototherapy units for acquiring maximum possible benefit and outcome.

Financial or other competing interests: None.

Disclosure forms provided by the authors are available with the full text of this article at jemds.com.

\section{REFERENCES}

[1] Vreman HJ, Wong RJ, Stevenson DK. Phototherapy: current methods and future directions. Semin Perinatol 2004;28(5):326-33.

[2] Dobbs RH, Cremer RJ. Phototherapy. Arch Dis Child 1975;50(11):833-6.

[3] Cremer RJ, Perryman PW, Richards DH. Influence of light on the hyperbilirubinemia of infants. Lancet 1958;1(7030):1094-7.

[4] Kapoor CL, Murti CR, Bajpai PC. Role of human skin in the photodecomposition of bilirubin. Biochem J 1974;142(3):567-73.

[5] Vogl TP. Phototherapy of neonatal hyperbilirubinemia: bilirubin in unexposed areas of the skin. J Pediatr 1974;85(5):707-10.

[6] Rubaltelli FF, Carli M. The effect of light on cutaneous bilirubin. Biol Neonate 1971;18(5):457-62.

[7] Ostrow JD. Mechanisms of bilirubin photodegradation. Sernin Henmatol 1972;9(2):113-25.

[8] Polin RA. Managment of neonatal hyperbilirubinemia: rational use of phototherapy. Biol Neonate I990;(Suppl 58):32-43.

[9] Costarino AT, Ennever JF, Buamgart S, et al. Bilirubin photoisomerization in premature neonates under lowand high-dose phototherapy. Pediatrics 1985;75(3):51922.

[10] Ennever JF. Blue light, green light, white light, more light: treatment of neonatal jaundice. Clin Perinatol 1990:17(2):467-81.

[11] Ennever JF, Knox I, Spec WT. Differences in bilirubin isomer composition in infants treated with green and white light phototherapy. J Pediatr 1986;109(1):119-22. 
[12] National Institute of Child Health and Human Development randomized, controlled trails of phototherapy for neonatal hyperbilirubinemia. Pediatrics 1985;75(2 Pt 2):385-441.

[13] Ennever JE. Phototherapy for neonatal Jaundice. Photochem Photobiol 1988;47(6):871-6.

[14] Ennever JF, Knox I, Denne CS, et al. Phototherapy for neonatal Jaundice: in vivo clearance of bilirubin photoproducts. Pediatr Res 1985;19(2):205-8.

[15] Maisels MJ. Avery neonatology pathophysiology and management of the newborn. In: Neonatal Jaundice. $3^{\text {rd }}$ edn. Philadelphia: JB Lippincott Co., 1987: p. 534-629.

[16] Ennever JF. Phototherapy for neonatal Jaundice. In: Polin RA, Fox WA, eds. Fetal and neonatal physiology. Philadelphia: W. B. Saunders 1991: p. 1165-72.

[17] Tan KL. Phototherapy for neonatal jaundice. Clin Perinatol 1991;18(3):423-39.

[18] Stutchfield PR, Modi N, Weindling AM. Phototherapy and the use of heat shields in very low birthweight infants. Arch Dis Child 1988;63(5):552-4.

[19] Cockington RA. A guide to the use of phototherapy in the management of neonatal by perbilirubinemia. J Pediatric 1979;95(2):281-5.

[20] Caravalho M, Lopes JMA. Qual o tempo de vida util de Himpada fluorescentes para fototerapia / What the time of life useful of fluorescent bulbs for phototerapy. J Pediatria 1991;67(5/6):151-6.

[21] Perlman M. The NICHD phototherapy study. Pediatrics 1990;86(5):811-12.

[22] Caravalho M, Lopes JMA. Fototerapia nos hospitais publicos do rio de janerio. J Pediatria 1991;67(5/6):15762.

[23] Taksande A, Selvam S. Side effects of phototherapy in neonatal hyperbilirubinemia. Acta Scientific Paediatrics 2018;1(5):24-30.

[24] McDonagh Af, Lightner DA. Like a shrivelled blood orange--bilirubin, jaundice and phototherapy. Pediatrics 1985;75(3):443-54.

[25] Montealegre A, Charpak N, Parra A, et al. Effectiveness and safety of two phototherapy devices for the humanised management of neonatal jaundice. An Pediatr (Barc) 2020;92(2):79-87.

[26] Bhat JI, Qazi IA, Ahangar AA, et al. Efficacy of different types of phototherapy devices: a 3 year prospective study from Northern India. J Clin Neonatol 2016;5(3):153-6.

[27] Adhikari KM, Mathai SS, Moorthy SM, et al. Efficacy of different types of phototherapy units on neonatal hyperbilirubinemia. J Mar Med Soc 2017;19(2):99-102.

[28] Ju SH, Lin CH. The effect of moderate non-hemolytic jaundice and phototherapy on newborn behavior.
Zhonghua Min Guo Xiao Er Ke Yi Xue Hui Za Zhi 1991;32(1):31-41.

[29] Maayan-Metzger A, Yosipovitch G, Hadad E, et al. Transepidermal water loss and skin hydration in preterm infants during phototherapy. Am J Perinatol 2001;18(7):393-6.

[30] De Curtis M, Guandalini S, Fasano A, et al. Diarrhoea in jaundiced neonates treated with phototherapy: role of intestinal secretion. Arch Dis Child 1989;64(8):1161-4.

[31] Gheshmi AN, Naderi S, Homyrani E, et al. Prevalence of hypocalcemia after phototherapy among neonates who underwent phototherapy in Koodakan Hospital in Bandar Abbas in 2013. Electron Physician 2015;7(6):1387-90.

[32] Chen A, Du L, Xu Y, et al. The effect of blue light exposure on the expression of circadian genes: bmal1 and cryptochrome 1 in peripheral blood mononuclear cells of jaundiced neonates. Pediatr Res 2005;58(6):1180-4.

[33] Xiong T, Qu Y, Cambier S, et al. The side effects of phototherapy for neonatal jaundice: what do we know? What should we do? Eur J Pediatr 2011;170(10):1247-55.

[34] Gromisch DS, Lopez R, Cole HS, et al. Light (phototherapy)--induced riboflavin deficiency in the neonate. J Pediatr 1977;90(1):118-22.

[35] Lucas A, Bates CJ. Occurrence and significance of riboflavin deficiency in preterm infants. Biol Neonate 1987;52(Suppl 1):113-8.

[36] Paller AS, Eramo LR, Farrell EE, et al. Purpuric phototherapy-induced eruption in transfused neonates: relation to transient porphyrinemia. Pediatrics 1997;100(3 Pt 1):360-4.

[37] Ioannou YA, Chen FW. Quantitation of DNA fragmentation in apoptosis. Nucleic Acids Res 1996;24(5):992-3.

[38] Tatli MM, Minnet C, Kocyigit A, et al. Phototherapy increases DNA damage in lymphocytes of hyperbilirubinemic neonates. Mutat Res 2008;654(1):935.

[39] Khera S, Gupta R. Incidence of thrombocytopenia following phototherapy in hyperbilirubinemic neonates. Med J Armed Forces India 2011;67(4):329-32.

[40] Das RR, Naik SS. Neonatal hyperbilirubinemia and childhood allergic diseases: a systematic review. Pediatr Allergy Immunol 2015;26(1):2-11.

[41] Matichard E, Le Hénanff A, Sanders A, et al. Effect of neonatal phototherapy on melanocytic nevus count in children. Arch Dermatol 2006;142(12):1599-604.

[42] Liu GS, Wu H, Wu BQ, et al. Effect of phototherapy on blood endothelin and nitric oxide levels: clinical significance in preterm infants. World J Pediatr 2008;4(1):31-5. 